\title{
Federal procurement of unlicensed medicines in Brazil; findings and implications
}

Cristiane Roberta dos Santos Teodoro ${ }^{1}$, André Luís Almeida dos Reis ${ }^{2}$, Brian Godman ${ }^{3,4}$, Rosângela Caetano ${ }^{4}$, Claudia Garcia Serpa Osorio-de-Castro ${ }^{1}$

${ }^{1}$ Center for Pharmaceutical Policies, Sergio Arouca National School of Public Health, Oswaldo Cruz Foundation, Rio de Janeiro, Brazil. Email: criss teodoro@yahoo.com.br; claudiaosorio.soc@gmail.com

${ }^{2}$ Brazilian National Regulatory Agency (ANVISA), Brasilia, Brazil. Email: andre.luis@anvisa.gov.br

${ }^{3}$ Strathclyde Institute of Pharmacy and Biomedical Sciences, University of Strathclyde, Glasgow, UK. Email: Brian.Godman@ @strath.ac.uk

${ }^{4}$ Division of Clinical Pharmacology, Karolinska Institutet, Stockholm, Sweden. Email:

Brian.Godman@ki.se

${ }^{5}$ Social Medicine Institute, Rio de Janeiro State University, Rio de Janeiro, Brazil.

Email: caetano.r@gmail.com

*Author for correspondence: Brian Godman, Division of Clinical Pharmacology, Karolinska Institute, Karolinska University Hospital Huddinge, SE-141 86, Stockholm, Sweden. Email: Brian.Godman@ki.se. Telephone + 468 58581068. Fax + 468 59581070 and Strathclyde Institute of Pharmacy and Biomedical Sciences, University of Strathclyde, Glasgow G4 0RE, United Kingdom. Email: brian.godman@ @strath.ac.uk. Telephone: 0141548 3825. Fax: 01415522562 and

(Accepted for publication Expert Review of Pharmacoeconomics and Outcomes Research - Please keep CONFIDENTIAL)

Key words: federal government, medicines, procurement, licensing, Brazil

\begin{abstract}
Background: There are safety concerns with using unlicensed medicines across countries including Brazil. Consequently, this needs to be evaluated and concerns address if pertinent. Aim: Investigate such purchases by the Brazilian Federal Government from 2004 to 2013. Methods: Procurement data from a public-access databank that contains procurement information of the Brazilian Federal Government. Each procured item was cross-referenced to its active drug approval status in the Brazilian National Register (DOU). Exploratory analysis and trend measures were performed for the variables for mapping and characterizing the purchases of non-market approved drugs. Results: $614(0.14 \%)$ purchases in ten years corresponding to 65 unlicensed medicines - some of which had orphan drug status - and 48 different active substances; with a growing trend in recent years. Medicines in 51\% of purchases were procured before obtaining marketing approval - with eventual refusals occurring in $17.8 \%$ and cancellation due to lack of efficacy and/or safety concerns in $1.1 \%$. Health litigation accounted for $81.9 \%$ of purchases and growing in recent years. Conclusions: Overall a low rate of unlicensed medicine use. However, there are concerns given the current regulations in Brazil and the recent increase in the use of unlicensed medicines with increased litigation.
\end{abstract}


Key words: Brazil, drug approval, federal government, procurement, unlicensed medicines

\section{Introduction}

Risks associated with medicines devoid of robust evidence of safety and efficacy are not uncommon. Withdrawals of medicines are much more frequent for problems regarding safety than for a lack of efficacy [1]. Several years may go by with hazardous exposure before a licensed medicine - approved by a regulatory body - may be removed from the market [1-4]. Careful assessment of new medicines for first-time approval, or subsequent re-approval or withdrawal, aims to protect patients and save important resources. This is especially important if the new medicine is to be used in a patient population with greater numbers of elderly, and a broader range of co-morbidities, than seen in the clinical trials [1-3].

In Brazil, licensing is mandatory for all marketed medicines (imported or locally produced). Drug approval is the responsibility of the Ministry of Health $(\mathrm{MoH})$ through the Brazilian Health Surveillance Agency (ANVISA). Medicines were originally licensed for a five-year period [5], after which a new assessment for renewal had to be made. Recent legislation has expanded this period to ten years, depending on the type of medicine and the health risk involved [6]. Drugs for rare diseases, defined in Brazil as those affecting 65 in 100.000 individuals, receive orphan drug status [7,8], but are also subject to the same regulation. Experimental medicines under clinical control are exempt for licensing requirements for a three-year period. After this period, the medicine must undergo assessment for market approval [5]. In 2013 and 2014, Brazilian regulatory authorities published measures to speed up the drug approval process introducing multiple flexibilities for concession of licenses or for the waiver of licensing requirements $[9,10]$.

Brazilian legislation also impedes dispensing and financing of unlicensed medicines in all levels of the public health system [11]. A fundamental requirement for the public procurement of medicines is a valid license. Specific legislation also stipulates that the government may only supply licensed medicines in evidence-based indications [5].

Health management in Brazil has been plagued by litigation since the late 1980s. Jurisprudence in Brazil understands health as a fundamental right and access to medicines as a means to attain health. Litigation for access to pharmaceuticals and health products warrants total access to plaintiffs' demands. Objects of litigation sometimes include medicines and procedures without marketing authorization or unavailability in the Brazilian Health System (SUS). Paradoxically, arbitrary interpretation of this rule may lead to the supply of medicines which have not undergone adequate efficacy and safety assessments [12-14], and may not provide value for money. This has proven to be an opportunity for pharmaceutical companies to further exert a strong influence on prescribers and patient organizations, enlarging markets for costly medicines, including new formulations [14]. There is now evidence that lawsuits have prompted the incorporation of some new medicines into Brazilian government funding lists, even without clear superiority of efficacy, safety, quality or cost-effectiveness, compared to already available therapies [15]. Health litigation for access to medicines may also lead to judicial enforcement of purchases of medicines devoid of a valid license $[13,16]$. 
To our knowledge, no information on procurement of unlicensed medicines in Brazil has yet been published. Consequently, there is a need to monitor government purchases, and possibly disclose important trends on medicine adoption and procurement, that may circumvent licensing. This study aims to investigate purchases of unlicensed medicines by the Brazilian Federal Government, from 2004 to 2013 as a basis for recommending future initiatives if pertinent.

\section{Methods}

We used the General Services Administration Database (Sistema Integrado de Administração de Serviços Gerais - SIASG), a public-access data bank that contains tendering information of the Brazilian Federal Government, for our longitudinal study.

Purchases with incomplete identification of medicines, according to the Brazilian Nonproprietary Name (INN), dosage form and concentration, were excluded.

Subsequent exclusions were purchases of (i) compounded medicines, (ii) medicines that had a license waiver according to ANVISA regulations [17] and (iii)

radiopharmaceuticals (for which licensing regulations only began in 2009).

In order to cross-check licensing information of medicines in individual purchases obtained in SIASG, we consulted the Brazilian National Register, the daily posting of the Brazilian Federal Government (Diário Oficial da União - DOU) and documents from ANVISA for active licensing status.

Expenditure of unlicensed medicines were obtained through total volume and price of each item, and adjusted to December 2013, by means of a widely used pricing deflator, the IPCA (Índice de Preços ao Consumidor Amplo - IPCA) obtained from the Institute of Applied Economic Research (Instituto de Pesquisa Econômica Aplicada - IPEA http://www.ipeadata.gov.br/IBGE). Expenditures were expressed in US\$ using the 2013 mean annual exchange rate (1US\$ $=\mathrm{R} \$ 2.157$ ) according to the U.S. Federal Reserve Bank (https://www.federalreserve.gov/releases/g5a/current/). Medicines responsible for major expenditures in the period were identified and their costs per monthly treatment of a $70 \mathrm{~kg}$ adult calculated and inserted.

Six categories of unlicensed medicines were identified: (a) license obtained after purchase; (b) license cancelled by ANVISA for lack of efficacy and/or safety reasons; (c) license expired; (d) first license or renewal refused by ANVISA; (e) unlicensed concentration and/or dosage form; (f) license cancellation claimed by the manufacturer, and (g) license not found. Medicines were cross-checked for their 'orphan drug status' according to FDA regulations [18]. This is because in Brazil there is no drafted list of orphan drugs; consequently, the FDA list was used. Drugs for rare diseases are referred to as orphan drugs in the US. The FDA defines rare disease as (a) those affecting less than 200,000 people and (b) as those affecting more than 200,000 people but for which there is no 'reasonable expectation' of development of a drug that will have its development costs recovered from sales within the country [18].

Information was obtained for the following variables: date of purchase, name of drug, dosage form and concentration, purchase strategy (tender, auction, tender waiver due to a variety of situations, including sole source), purchasing justification (regular/emergency procurement, litigation-related procurement, no information) and 
name of purchasing institution (Ministry of Health, Ministry of Education, Ministry of Defense and others). Unlicensed medicines were classified by the Anatomical Therapeutic Chemical Classification (ATC) System, to the fourth or fifth level when this existed (http://www.whocc.no/atc_ddd_index/).

Exploratory analysis was performed for all variables, using the Excel software (Microsoft Corp. United States). Linear tendencies were plotted for the following variables: number of purchases, number of unlicensed medicines and number of active substances purchased along the period. Expenditure trends were plotted using moving averages method, because of intense variation and small magnitude. This method is a statistical indicator that helps to minimize acute fluctuations and show longer-term trends [19]. There were no ethical constraints to data access or analysis, since the entire study was based on public-access data. Ethical legislation exempted the study from institutional ethics committee approval [20].

\section{Results}

From 2004 to 2013, 465,203 purchases of medicines with complete information were registered in SIASG. Of these, 18,083 were excluded, resulting in 447,120 purchases examined as to licensing status. There were $614(0.14 \%)$ purchases of unlicensed medicines in the ten-year period, with a total expenditure of approximately US\$169 million. Figure 1 shows the trends for the number of purchases, unlicensed medicines, active substances and expenditures. 
Figure 1. Federal Government Purchases: number and trend of purchases of unlicensed medicines (A), unlicensed medicines (B), active substances (C) and expenditures in USD (D). Brazil, 2004-2013
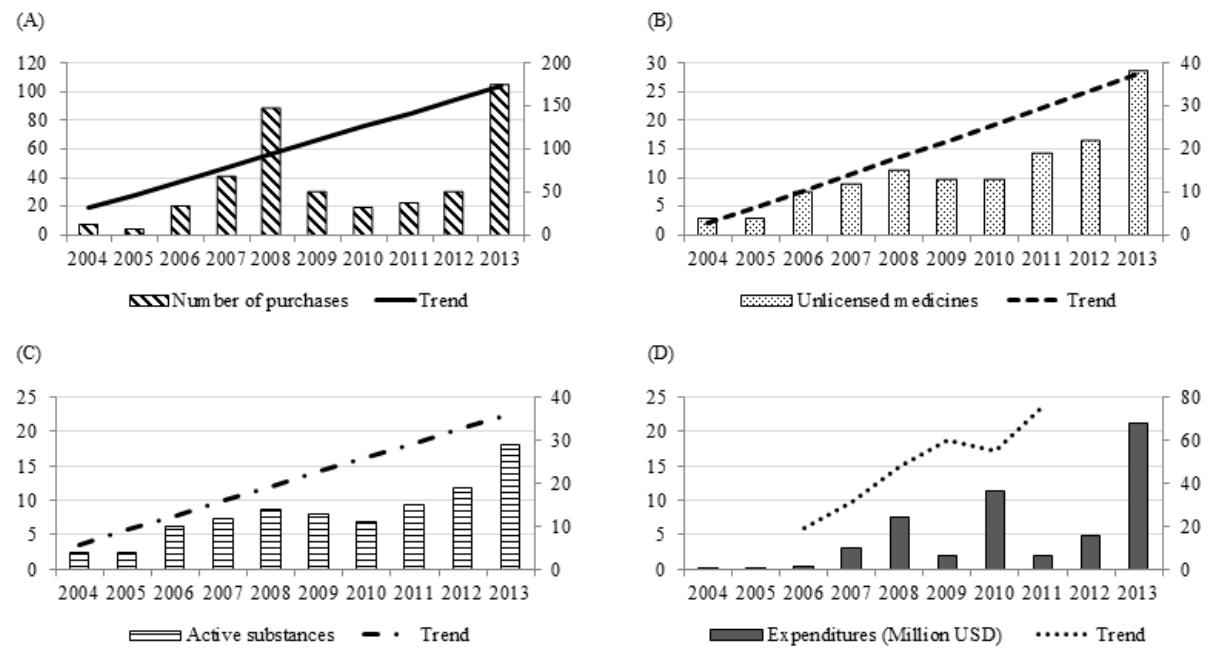

These 614 purchases correspond to 65 unlicensed medicines (active substance, strength and dosage form), comprising 48 different active substances. From 2004, the number of unlicensed medicines showed a slight increase over time. The number of purchases peaked in 2008 (147 purchases, 15 different medicines and 14 distinct active substances) and in 2013 (174 purchases, 38 medicines and 29 active substances) (Figure 1). Expenditures for 2008 and 2013 were USD 24 and USD 68 million, respectively. In 2008, galsulfase $1 \mathrm{mg} / \mathrm{mL}$ accounted for 59.9\% (88/147) of purchases, while in 2013 $39.7 \%(69 / 174)$ of purchases were for eculizumab $10 \mathrm{mg} / \mathrm{mL}$.

Among the 48 different active substances present in medicines with an unlicensed status, 20 (corresponding to 30 different medicines) were medicines that were used for the treatment of rare diseases. In the ten-year period, three medicines had considerable expenditure: eculizumab (USD 370,654,400.79), taliglucerase alfa (USD 128,066,691.25) and galsulfase (USD 86,059,574.27). All three are considered orphan drugs, employed for rare diseases: eculizumab for paroxysmal nocturnal haemoglobinuria (PNH), taliglucerase alfa for Gaucher's disease and galsulfase for treatment of Mucopolyssacharidosis Type VI (Maroteaux-Lamy disease). For a 70kg adult, a one-month treatment with eculizumab cost approximately USD 2.25 million, while for taliglucerase alfa the cost per patient per month is USD3660. A one-month treatment with galsulfase costs approximately USD516000. 
Box 1 presents active substances according to unlicensed medicine categories. Medicines in more than half of total purchases were procured before obtaining marketing authorization (51\%). Licensing refusal occurred in $17.8 \%$ of purchases and cancellation due to safety concerns and/or lack of efficacy in $1.1 \%$.

$\underline{\text { Box 1. Purchases of unlicensed medicines, according to category. Brazil, 2004-2013 }}$

\begin{tabular}{|c|c|c|}
\hline Category & $\begin{array}{l}\text { Number of } \\
\text { purchases }(\%)\end{array}$ & Medicine \\
\hline $\begin{array}{l}\text { license obtained after } \\
\text { purchase }\end{array}$ & $313(51.0)$ & $\begin{array}{l}\text { agalsidase alfa } 1 \mathrm{mg} / \mathrm{mL} \text { injectable*, taliglucerase alfa } 200 \\
\text { UI injectable*, brentuximab vedotine } 50 \mathrm{mg} \text { injectable*, } \\
\text { cinacalcet } 30 \mathrm{mg} \text { capsule*, C1 esterase inhibitor } 500 \mathrm{UI} \\
\text { injectable, darunavir } 300 \mathrm{mg} \text { tablet, dasatinib } 100 \mathrm{mg} \\
\text { tablet*, erlotinib } 100 \mathrm{mg} \text { tablet, erlotinib } 150 \mathrm{mg} \text { tablet, } \\
\text { etravirine } 100 \mathrm{mg} \text { tablet, fidaxomicin } 200 \mathrm{mg} \text { tablet, } \\
\text { galsulfase } 1 \mathrm{mg} / \mathrm{mL} \text { injectable*, gefitinib } 250 \mathrm{mg} \text { tablet*, } \\
\text { idursulfase } 2 \mathrm{mg} / \mathrm{mL} \text { injectable*, lacosamide } 50 \mathrm{mg} \text { tablet, } \\
\text { tipranavir } 250 \mathrm{mg} \text { capsule, tirofiban } 0.25 \mathrm{mg} / \mathrm{mL} \text { injectable }\end{array}$ \\
\hline license not found & $131(21.3)$ & $\begin{array}{l}\text { eculizumab } 10 \mathrm{mg} / \mathrm{mL} \text { injectable*, stiripentol } 500 \mathrm{mg} \\
\text { capsule, nitisinone } 5 \mathrm{mg} \text { capsule*, nitisinone } 10 \mathrm{mg} \\
\text { capsule*, pegaspargase } 750 \mathrm{UI} / \mathrm{mL} \text { injectable*, ponatinib } \\
45 \mathrm{mg} \text { tablet*, rufinamide } 200 \mathrm{mg} \text { tablet, tafamidis } 20 \mathrm{mg} \\
\text { capsule, tetracosactide } 0.25 \mathrm{mg} \text { injectable, tetracosactide } 1 \\
\text { mg/mL injectable, trientine } 250 \mathrm{mg} \text { tablet* }\end{array}$ \\
\hline $\begin{array}{l}\text { first license or renewal } \\
\text { refused }\end{array}$ & $109(17.8)$ & $\begin{array}{l}\text { clofarabine } 1 \mathrm{mg} / \mathrm{mL} \text { injectable, foscarnet } 24 \mathrm{mg} / \mathrm{mL} \\
\text { injectable, hematin } 25 \mathrm{mg} / \mathrm{mL} \text {, lenalidomide } 5 \mathrm{mg} \text { capsule*, } \\
\text { lenalidomide } 10 \mathrm{mg} \text { capsule*, lenalidomide } 25 \mathrm{mg} \\
\text { capsule*, levetiracetam } 250 \mathrm{mg} \text { tablet, levetiracetam } 500 \\
\text { mg tablet, lomitapide } 5 \mathrm{mg} \text { capsule*, lomitapide } 10 \mathrm{mg} \\
\text { capsule*, lomitapide } 20 \mathrm{mg} \text { capsule*, mercaptamine } 50 \mathrm{mg} \\
\text { capsule*, mercaptamine } 150 \mathrm{mg} \text { capsule*, mercaptamine } \\
6,5 \mathrm{mg} / \mathrm{mL} \text { ophthalmic solution*, regorafenib } 40 \mathrm{mg} \\
\text { tablet*, ruxolitinib } 5 \mathrm{mg} \text { tablet* }\end{array}$ \\
\hline license expired & $36(5.9)$ & $\begin{array}{l}\text { artesunate } 50 \mathrm{mg} \text { tablet, cidofovir } 75 \mathrm{mg} / \mathrm{mL} \text { injectable, } \\
\text { disopyramide } 250 \mathrm{mg} \text { dragee, miltefosine } 5 \mathrm{mg} \text { capsule*, } \\
\text { miltefosine } 10 \mathrm{mg} \text { capsule*, pentamidine } 300 \mathrm{mg} \\
\text { injectable, pentosan } 100 \mathrm{mg} \text { capsule, procarbazine } 50 \mathrm{mg} \\
\text { capsule, thymalfasine } 1.6 \mathrm{mg} \text { injectable }\end{array}$ \\
\hline $\begin{array}{l}\text { unlicensed } \\
\text { concentration and/or } \\
\text { dosage form }\end{array}$ & $17(2.8)$ & $\begin{array}{l}\text { denosumab } 70 \mathrm{mg} / \mathrm{mL} \text { injectable*, diazoxide } 25 \mathrm{mg} \\
\text { capsule, diazoxide } 50 \mathrm{mg} / \mathrm{mL} \text { oral suspension, hematin } 313 \\
\text { mg injectable, sultiame } 50 \mathrm{mg} \text { tablet }\end{array}$ \\
\hline $\begin{array}{l}\text { license canceled for } \\
\text { safety reasons and/or } \\
\text { lack of efficacy }\end{array}$ & $7(1.1)$ & $\begin{array}{l}\text { drotrecogin alfa } 5 \mathrm{mg} \text { injectable, drotrecogin alfa } 20 \mathrm{mg} \\
\text { injectable, rosiglitazone } 4 \mathrm{mg} \text { tablet, rosiglitazone } 8 \mathrm{mg} \\
\text { tablet }\end{array}$ \\
\hline $\begin{array}{l}\text { license cancelation } \\
\text { claimed by the } \\
\text { manufacturer }\end{array}$ & $1(0,2)$ & barbexaclone $100 \mathrm{mg}$ tablet \\
\hline
\end{tabular}

*Orphan drug status (FDA, 2017)

Table 1 shows purchases according to ATC classification (therapeutic subgroup). Purchases of medicines acting in the alimentary tract and metabolism $(29.0 \%)$ and immunosuppressants (18.6\%) were predominant. 
Table 1. Purchases of unlicensed medicines, according to ATC classification. Brazil, $\underline{\text { 2004-2013 }}$

\begin{tabular}{|c|c|}
\hline Therapeutic Subgroup & Number of purchases $(\%)$ \\
\hline $\begin{array}{l}\text { A16 - Alimentary tract an } \\
\text { metabolism }\end{array}$ & $178(29.0)$ \\
\hline L04 - Immunosuppressants & $114(18.6)$ \\
\hline B01 - Antithrombotic agents & $83(14.4)$ \\
\hline J05 - Antivirals for systemic use & $42(6.8)$ \\
\hline N03 - Antiepileptics & $41(6.7)$ \\
\hline C10 - Lipid modifying agents & $34(5.5)$ \\
\hline L01 - Antineoplastic agents & $33(5.4)$ \\
\hline Others & $89(14.5)$ \\
\hline
\end{tabular}

The Ministry of Health $(\mathrm{MoH})$ was responsible for the majority (86.0\%) of unlicensed medicines purchases.

The predominant purchase strategy was unspecified tender waiver carried out for 511 $(83.2 \%)$ purchases, the majority of which $(96.9 \%)$ were implemented by the Ministry of Health. Auctions accounted for 80 purchases of which $51.3 \%$ were performed by the Ministry of Education.

Purchasing justification was not informed in $13.8 \%$ of purchase entries, with a marked decrease in the last three years of the study period (0.49\% in 2013). Health litigation accounted for $81.9 \%$ of total purchases of unlicensed medicines in Brazil between 2004 to 2013. In 2013, however, health litigation alone was responsible for $96.6 \%$ of purchases (Figure 2). 
Figure 2. Purchasing justification of procured unlicensed medicines. Brazil, 2004-2013

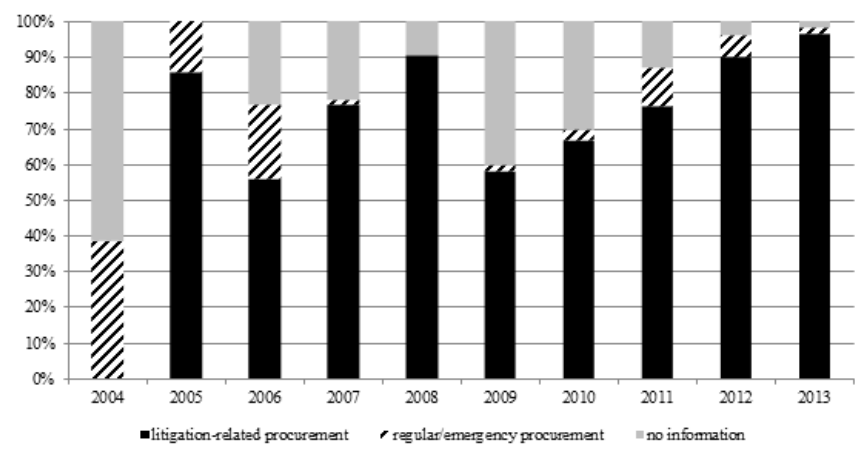

\section{Discussion}

During the ten-year period, the Brazilian Government procured a variety of unlicensed medicines, some of which were bought repeatedly, contrary to federal law, with all variables showed a rising trend over the ten-year period (Figure 1). This observation may indicate several factors are involved including prescriptions outside of official treatment protocols, pressures exerted by litigation for unlicensed medicines [13], or the flexibility of import regulations, facilitating the purchase of unlicensed medicines [9].

Whilst the overall number of purchases of unlicensed medicines is small $(0.14 \%)$, the rise in unlicensed medicines purchases in 2013 is worrying and may be associated with new legislation. Decree ${ }^{\circ} 8,077 / 2013$ exempts from market approval strategic pharmaceuticals and health products supplied by international organizations for use in government programs. Moreover, the new legislation eases government medicines purchases through simplified licensing procedures in the case of severe health risks or absence of licensed therapeutic alternatives [9].

In addition, although the number of federal purchases of unlicensed medicines has overall been small, the event itself should have been exceptionally rare. Purchases of unlicensed medicines violate article 19-T of Law 12.401/2011, which explicitly states that the government may not pay for or reimburse locally produced or imported unlicensed medicines or products; or experimental clinical or surgical procedures or products, or any such products or procedures unauthorized by ANVISA [11]. 
Several of the medicines had orphan status. Seventeen medicines involved in large numbers of purchases (313) obtained licenses after their purchase. Agalsidase alfa 1 $\mathrm{mg} / \mathrm{mL}$ (injectable), cinacalcet $30 \mathrm{mg}$ (capsule), galsulfase $1 \mathrm{mg} / \mathrm{mL}$ (injectable), gefitinib $250 \mathrm{mg}$ (tablet), idursulfase $2 \mathrm{mg} / \mathrm{mL}$ (injectable), lacosamide $50 \mathrm{mg}$ (tablet), tipranavir $250 \mathrm{mg}$ (capsule) and tirofiban $0.25 \mathrm{mg} / \mathrm{mL}$ (injectable) were purchased continuously for three years or more, before obtaining marketing authorization. Increases in unlicensed purchases in light of new flexibilities, might actually result in more rapid licensing and adoption by the health system, perpetuating this cycle [21]. Recurrent purchases of several unlicensed medicines over time may represent one of two situations: either a pressure mechanism for obtaining marketing approval or as purposeful neglect of medicine regulation in the country.

Other significant purchases were related to the refusal of the first license or of renewal (109), which is a noteworthy finding, considering ANVISA's role as a regulatory agency. In ANVISA's website, information on this issue is not forthcoming and a generic label ('non-conformity to legislation') is given as a reason for refusal [22]. A relevant point must be made regarding the availability and transparency of information in ANVISA's website, which may have an important bearing upon our results. Lack of information, unavailability of market approval histories, and overall delay in information updates were difficulties encountered during data collection and analysis.

The time span for market approval procedures in Brazil has been variable [23] in spite of 90-day threshold established by current legislation. No licensing information was found for 131 purchases, which may be explained by perceived length of market approval time, leading to disinterest in licensing submission. Moreover, manufacturers may not be interested in licensing their new medicine in each country. Greater profits may result from health litigation, since it obliges the government to buy medicines, licensed or not, commanding higher prices and less competition because of emergency procurement procedures $[14,16]$.

Four medicines had licenses cancelled due to safety reasons and/or lack of efficacy. Drotrecogin alfa was voluntarily removed from the international market by Eli Lilly due to failure to show a survival benefit and excessive bleeding. Rosiglitazone had its approval cancelled by ANVISA and by the European Medicines Agency (EMA) due to severe cardiovascular effects.

The recent Brazilian legislation [10] considers authorized importation of unlicensed medicines for individual use in exceptional circumstances. Various unlicensed medicines, including products with an expired license or with a license refusal that were identified by this study, are present in the list of medicines issued by ANVISA for this purpose [24]. These cases highlight the importance of a regulatory agency's role. Efficacy and safety are central to pharmaceutical regulation, which in the present situation appears second in line to demands and pressures resulting from litigation. In our study, health litigation was an overwhelming factor for purchases of unlicensed medicines. In the last year of the study period, the proportion of purchases resulting from litigation rose to $96.6 \%$ of total purchases. This result is corroborated by several studies that show the use of judicial demands as a strategy for obtaining access to marketing approval or unlicensed medicines in Brazil $[13,14]$, while ignoring health regulations and exposing users to unnecessary health hazards. Since the early 1990s, litigation has involved not only high-cost medicines and those for overall high-cost treatments, but also 
Primary Health Care (PHC) medicines that may not be delivered in a timely fashion by municipal governments. According to the law, responsibilities for delivery are very specific - municipal governments should dispense PHC medicines, States some high-cost drugs and the federal level must deliver medicines for neglected diseases and most of the very costly newer medicines.

Not surprisingly, the Ministry of Health is the main federal purchasing agent of unlicensed medicines. In Brazil, litigation against the public health system has been rising steeply in the last few years and, in spite of state and municipal roles as defendants, very high-cost medicines demands usually bring the Ministry to court, because highly-complex care is concentrated in federal and university hospitals $[13,25,26]$.

Alimentary Tract and Metabolism Agents, Immunosuppressants, and Antithrombotic Agents formed the majority of unlicensed medicines, due to great number of purchases related to galsulfase (A16AB08), lenalidomide (L04AX04) and tirofiban (B01AC17), respectively. For the A16 subgroup, especially, $98.9 \%$ of purchases during the 10 -year period were consequences of litigation. However, not all unregistered medicines were expensive (exceptions, for instance, include miltefosine, barbexaclone, and lacosamide). But most of the A16 medicines are very high-cost enzymes for rare diseases, such as Gaucher's disease and for PNH. The extreme costs calculated for monthly treatments may be result of litigation but may alternatively be due to lack of negotiations to lower prices. The median prices we obtained coincide with those from 2014 [27]. Sartori and co-workers (2012) examined litigation for agalsidase alfa in the state of Rio Grande do Sul until 2007, and found that most prescriptions originated in university hospitals. At this time, agalsidase alfa had been approved by the EMA, but licensing in Brazil only happened in 2009 [28].

Litigation has spread in Brazil, appreciably increasing medicine expenditure in the states, municipalities and Federal Government. Ministry of Health $(\mathrm{MoH})$ expenditures with health litigation have been estimated at US\$750 million from 2012 to 2014, with expenditure rising from US\$188.32 million in 2012 to US\$359.05 million in 2014 [29]. This is a growing concern especially regarding the particular characteristics of purchases resulting from litigation. Decisions are usually made in haste and medicines are not included in forecasting. Because purchases usually forgo regular tendering procedures, different waivers are applied, and the government is apt to relinquish bargaining power, resulting in higher costs for the system $[14,16]$.

As a result, health litigation frequently causes negative social consequences and produces detrimental resource allocation, causing strain on existing health services and particularly pharmaceutical services [30]. As a result, the goals of universal access to healthcare in Brazil may be difficult to sustain.

We accept that one of the limitations of this study on purchases of unlicensed medicines in Brazil is that it is based on secondary data. Although an original effort to approach the issue has been made, some limitations should additionally be mentioned. The SIASG database, although comprehensive in listing federal purchases, also presented inconsistencies regarding certain variables, such as the purchase strategy, purchasing justification and prices. In addition, existing information in the database is not always complete or self-explanatory. Nevertheless, the data bank has improved over the years, permitting a series of studies on federal procurement in Brazil [31,32]. It must be 
emphasized that SIASG procurement data offer a proxi for consumption and, as such, are not appropriate for inferences on actual consumption.

\section{Conclusion}

Our study presents the scenario of federal purchases of unlicensed medicines in Brazil from 2004 to 2013, as well as possible determinants and consequences.

Total volume of purchases of unlicensed medicines was very small, but the number of events, which should have been very rare, was observed to increase during the study period. Health litigation is an important determinant for this rise and may result in premature licensing and untoward adoption by the health system.

For these reasons, we recommend a careful review of purchase demands of unlicensed medicines and their submission to health assessment procedures before purchase. Although these purchases might be authorized in very exceptional circumstances, efficacy, safety, quality and effectiveness of medicines must be acknowledged. Given the current regulations and the context of health litigation in Brazil, the recent surge of unlicensed medicines procurement is likely to increase, which is a concern. Trends in purchases of unlicensed medicines should be looked into, especially determining the role of litigation. This is also important as Brazil's regulatory agency, ANVISA, is a reference for the Latin American region and several other Latin American countries are undergoing the same health litigation phenomenon, which is an increasing concern.

\section{Key messages}

- A valid license is a fundamental requirement for the public procurement of medicines in Brazil, and legislation binds the government to supply licensed medicines in evidence-based indications.

- Health litigation for access to medicines, however, has led to judicial enforcement of medicines purchases, disrupting normal pathways

- As a result, paradoxically, at times making drug approval regulations secondary to judicial decisions.

- An investigation from 2004 to 2013 showed that 65 unlicensed medicines were linked to 614 purchases over this ten-year span, with numbers rising in 2013

- Health litigation accounted for $81.9 \%$ of purchases during the ten-year period.

- Efficacy and safety are central to pharmaceutical regulation where patients are concerned, which at times appear secondary to demands and pressures resulting from litigation.

- Unlicensed medicines procurement in Brazil indicates the need for further strategies to protect public health and to make universal access sustainable. .

\section{Acknowledgements}

The Authors gratefully thank Antonio Carlos Bezerra (Anvisa), Maria Eugênia Vieira Martins (Anvisa) and Paulo Marques (Oswaldo Cruz Foundation) for support in data collection and analysis. 


\section{Financial disclosures and conflicts of interest}

The work was funded in part by the Brazilian Research and Development Council (CNPq). Grant Number 303342/2013-7

André Luís Almeida dos Reis is employed by ANVISA. However, the comments made in the paper may not necessarily reflect the thoughts of ANVISA. The other authors have no other relevant affiliations or financial involvement with any organization or entity with a financial interest in or financial conflict with the subject matter or materials discussed in the manuscript apart from those disclosed.

\section{References}

1. Malmström RE, Godman BB, Diogene E, et al. Dabigatran-a case history demonstrating the need for comprehensive approaches to optimize the use of new drugs. Frontiers in Pharmacology. $2013 ; 4: 1-31$.

2. Jüni P, Nartey L, Reichenbach S, et al. Risk of cardiovascular events and rofecoxib: cumulative meta-analysis. Lancet. 2004; 364: 2021-29.

3. Cohen D. Dabigatran: how the drug company withheld important analyses. BMJ. 2014; 349:g4670.

4. Failliel $\mathbf{J}$ and Hillaire-Buys D. Examples of how the pharmaceutical industries distort the evidence of drug safety: the case of pioglitazone and the bladder cancer issue Pharmacoepidemiol Drug Saf . 2016; 25: 212-214.

5. Brasil. Lei Federal $n^{0}$ 6.360, de 23 de setembro de 1976. Diário Oficial da União 1976. www.planalto.gov.br/ccivil_03/leis/16360.htm (accessed 16 March 2016).

6. Brasil. Lei Federal $n^{\circ}$ 13.097, de 19 de janeiro de 2015. Diário Oficial da União 2015. www.planalto.gov.br/ccivil_03/_Ato2015-2018/2015/Lei/L13097.htm (accessed 16 March 2016).

7. Brasil. Agência Nacional de Vigilância Sanitária (ANVISA). Glossário de definições legais. 2017. http://www.anvisa.gov.br/medicamentos/glossario/glossario_m.htm (accessed 10 mar 2017).

8. Brasil. Portaria $\mathrm{n}^{\circ}$ 199, de 30 de janeiro de 2014. Diário Oficial da União 2014. http://bvsms.saude.gov.br/bvs/saudelegis/gm/2014/prt0199_30_01_2014.html (accessed 10 March 2017).

9. Brasil. Decreto Federal no 8.077, de 14 de agosto de 2013. Diário Oficial da União 2013. www.planalto.gov.br/ccivil_03/_Ato2011-2014/2013/Decreto/D8077.htm (accessed 16 March 2016).

10. Brasil. Agência Nacional de Vigilância Sanitária (ANVISA). Resolução - RDC no 8, de 28 de fevereiro de 2014. Diário Oficial da União 2014. bvsms.saude.gov.br/bvs/saudelegis/anvisa/2014/rdc0008_28_02_2014.html (accessed 16 March 2016).

11. Brasil. Lei Federal $n^{\circ}$ 12.401, de 28 de abril de 2011. Diário Oficial da União 2011. http://www.planalto.gov.br/ccivil_03/_Ato2011-2014/2011/Lei/L12401.htm (accessed 11 March, 2015). 
12. Biehl J, Petryna A, Gertner A, et al. Judicialisation of the right to health in Brazil. Lancet. $2009 ; 373: 2182-84$.

13. Pepe VLE, Figueiredo TA, Simas L, et al. A judicialização da saúde e os novos desafios da gestão da assistência farmacêutica. Cien Saude Colet. 2010; 15:2405-14.

14. Chieffi AL and Barata RC. Ações judiciais: estratégia da indústria farmacêutica para introdução de novos medicamentos. Rev Saude Publica. 2010; 44:421-9.

15. Figueiredo TA, Schramm JM, Pepe VL. Seleção de medicamentos essenciais e a carga de doença no Brasil. Cad. Saude Publica. 2014; 30:2344-2356.

16. Pessoa HR. Decisões judiciais para fornecer medicamentos sem registro na ANVISA. Jus Navigandi. 2012; 17:3134. http://jus.com.br/artigos/20982 (accessed 12 mar 2016).

17. Brasil. Agência Nacional de Vigilância Sanitária (ANVISA). Resolução - RDC no 199, de 26 de outubro de 2006. http://www.anvisa.gov.br/divulga/noticias/2006/061106_rdc199.pdf. (accessed 14 mar 2016).

$\begin{array}{lllll}\text { 18.USA. Food and drug } & \text { administration }\end{array}$ https://www.fda.gov/ForIndustry/DevelopingProductsforRareDiseasesConditions/Howtoapplyf orOrphanProductDesignation/ucm364750.htm. Access: 10 mar 2017.

19. Harmsen SM, Chang YH, Hattrup SJ. Simple moving average: a method of reporting evolving complication rates. Orthopedics; 39:e869-76.

20. Brasil. Conselho Nacional de Saúde. Resolução n ${ }^{\circ}$ 466, de 12 de dezembro de 2012. Diário Oficial da União 2012. conselho.saude.gov.br/resolucoes/2012/Reso466.pdf (accessed 14 mar 2016).

21. Santos-Pinto CDB, Ventura M, Pepe, VLE, Osorio-de-Castro CGS. Novos delineamentos da Assistência Farmacêutica frente à regulamentação da Lei Orgânica da Saúde. Cad. Saude Publica. 2013; 29:1056-1058. DOI: 10.1590/S0102-311X2013000600002.

22. Brasil. Agência Nacional de Vigilância Sanitária (ANVISA). Orientação de serviço ${ }^{\circ} 02$ 2012/GGMED/ANVISA, de 20 de novembro de 2012. portal.anvisa.gov.br/wps/wcm/connect/5c96e7004d9aa60eb7cef7c116238c3b/OS+02-

2012+indeferimento+sem+exig\%C3\%AAncia.pdf.pdf?MOD=AJPERES (accessed 14 mar 2016).

23. Reddy ML, VamseedharNaik B, et al. Latin American Pharmaceutical Regulatory Environment - Review article. Int J Research in Pharmaceutical and Nano Sciences. 2014; 3:122131.

24. Brasil. Agência Nacional de Vigilância Sanitária (ANVISA). Instrução Normativa ${ }^{\circ}$ 01, de 28 de fevereiro de 2014. http://portal.anvisa.gov.br/documents/33880/2568070/int0001_28_02_2014.pdf/73203ebbc27c-4f05-85f5-730491704d5e (accessed 14 mar 2016).

25. Gomes VS and Amador TA. Estudos publicados em periódicos indexados sobre decisões judiciais para acesso a medicamentos no Brasil: uma revisão sistemática. Cad. Saude Publica. $2015 ; 31: 451-462$.

26. Reveiz L, Chapman E, Torres R, et al. Litigios por derecho a la salud en tres países de América Latina: revisión sistemática de la literatura. Rev Panam Salud Publica. 2013; 33:213-22. 
27. David, Andrelino \& Beghin. Avaliação das despesas com medicamentos no âmbito federal do Sistema Único de Saúde entre 2008 e 2015. Inesc.1 ${ }^{\text {a }}$ ed. Brasília/DF. 2016. http://www.inesc.org.br/biblioteca/publicacoes/textos/direito-a-medicamentos-avaliacao-dasdespesas-com-medicamentos-no-ambito-federal-do-sistema-unico-de-saude-entre-2008-e2015/view. Access: 10 mar 2017

28. Sartori Jr D, Leivas PGC, Souza MV, et al. Judicialização do acesso ao tratamento de doenças genéticas raras: a doença de Fabry no Rio Grande do Sul. Cien Saude Colet. 2012; 17:2717-2728.

29. Interfarma. Por que o brasileiro recorre à Justiça para adquirir medicamentos? 2016. http://www.interfarma.org.br/uploads/biblioteca/101-por-que-o-brasileiro-vai-a-justiaa-embusca-de-medicamentos-site.pdf. (accessed 15 oct 2016).

30. Inesta A and Oteo LA. La industria farmacéutica y la sostenibilidad de los sistemas de salud en países desarrollados y América Latina. Cienc. Saude Coletiva.2011; 16:2713-2724.

31. Luo J, Oliveira MA, Ramos MBC, Osorio-de-Castro CGS. Antiretroviral drug expenditure, pricing and judicial demand: an analysis of federal procurement data in Brazil from 2004-2011. BMC Public Health.2014; 14:367.

32. Costa RDF, Osorio-de-Castro CGS, Silva RM, et al. Aquisição de medicamentos para a Doença de Alzheimer no Brasil: uma análise no sistema federal de compras, 2008 a 2013. Cien Saude Colet 2015; 20:3827-3838. 